\title{
Fichte and Schelling: The Limitations of the Wissenschaftslehre?
}

\author{
Sebastian Gardner
}

In 1800 Fichte and Schelling began a correspondence in which they frankly addressed their philosophical differences, ${ }^{1}$ each alleging irreparable defects in the other's system and misunderstandings of their own. Their closing exchange in 1802, after which all direct communication between the two men ceased and mutual criticism became a feature of their published writings, brought to an end what had been originally and officially, ever since 1794, a relationship of philosophical cooperation, a common radical progressive front in the Kantian aftermath, confronting a single set of critics.

Concerning one thing at least, they remained in agreement: the doctrine which defines in bold their philosophical opposition is that of the reality of Nature, denied by Fichte and affirmed by Schelling. The disagreement is however by no means self-explanatory, for what it means to grant or deny Nature's reality is not, after Kant, a straightforward matter - Fichte is no Berkeleyan idealist and Schelling no Lockeian realist - and a lengthy route needs to be taken in order to understand how it evolved from what had been, to all appearances, a common post-Kantian starting point. The first two parts of my discussion trace accordingly the history of their philosophical relationship, with close attention to Schelling's earliest published works, often referred to as comprising the 'Fichtean' period in his development. The third reviews the systematic ground of their disagreement.

\section{The original alignment, 1794-95}

Fichte's Concerning the Concept of the Wissenschaftslehre, and Schelling's Of the Possibility of a Form of All Philosophy (Form-Schrift), both published in 1794, form a natural pair. Both assert, following Reinhold, that philosophy must become a system in the strongest sense, and the necessity, to that end, of its being grounded on a single principle, not furnished by Kant. Reinhold's own reconstruction, his 'Philosophy of Elements', they regard as a proven failure after the sceptical battering received by Kantianism at the hands of 'Aenesidemus' (Gottlob Ernst Schulze) and Salomon Maimon. What Reinhold has shown, they consider, is that Kant's philosophy cannot be saved by mere supplementation: systematicity can be achieved only by positing an I to which absoluteness, including absolute freedom, is ascribed. The Form-Schrift was written shortly after Schelling's exposure to the first published parts of the Grundlage der gesammten Wissenschaftslehre (1794-95), and in it Fichte is hailed as having alone put philosophy on the path

\footnotetext{
${ }^{1}$ Translated in Michael G. Vater and David W. Wood (eds.), The Philosophical Rupture between Fichte and Schelling: Selected Texts and Correspondence (1800-1802) (Albany, NY: SUNY Press, 2012). This invaluable edition collects a number of relevant texts.
} 
to completion. ${ }^{2}$ Yet, placing the two essays alongside one another, it is possible to detect differences of approach which, with the benefit of hindsight, can be seen to contain the seeds of the substantive disagreements that would eventually set them in flat opposition.

A clue lies in the title of Schelling's piece: to give primacy to the question of the 'form of philosophy', as Schelling understands it, is to take it that there is an idea of philosophy from which extrapolations can be made. This is done by attending to the pure concept of unity, since it is that concept which defines systematicity, whereby we isolate what Schelling calls the Urform, 'universal form' of all knowledge, and 'principle of the form of all form [Grundsatz der Form aller Form]'. ${ }^{3}$ And to grasp this 'original form' is itself to possess contentful philosophical knowledge.

Schelling's candid platonism, ${ }^{4}$ wholly absent from Fichte, is not yet, at this earliest stage, the full-fledged doctrine of eternal types that it later becomes, but of an original sort, mediated by his reading of Kant. Schelling assimilates Plato's ideas to Kant's ideas of reason, yet envisages no reduction of the former to the latter, of the sort that Kant himself recommends: ${ }^{5}$ instead, taking Plato's side, and apparently disregarding Kant's thesis of the necessary involvement of reason's ideas with dialectical illusion, Schelling's claim is that enquiry into ideas must take precedence in the order of philosophical reflection. His Kantianism, too, is therefore of a radically original kind: if ideas must be grasped at the outset, then what Kant designates as reason, Vernunft, the faculty of which generates ideas, has priority over the understanding, Verstand, and philosophy properly begins not with the analysis of experience - transcendental proof and explanation, the labour of articulating the 'conditions of possibility' of objects - but with reason's self-reflection. The intention of turning Kant on his head is reflected in Schelling's oft-quoted statement, in a letter to Hegel in 1795: 'Kant has provided the results. The premises are still missing. And who can understand results without premises?'

Now Fichte of course also believes that Kant's philosophy is lacking the metaphilosophy it badly needs, and that Kant has not formulated satisfactorily the method of transcendental proof, but his argument in Concerning the Concept for strong systematicity is independent of the sorts of

\footnotetext{
${ }^{2}$ Form-Schrift, in The Unconditional in Human Knowledge: Four Early Essays 1794-1796, ed. Fritz Marti (Lewisburg: Bucknell University Press, 1980), 39 [I, 88-89]. References to Schelling in square brackets are to Schellings sämmtliche Werke, 14 vols., ed. Karl Friedrich August Schelling (Stuttgart: Cotta, 1856-61). See also Schelling's letter to Hegel, 5 January 1795 (Aus Schellings Leben, in Briefen, Bd. 1, 1775-1803, ed. G. L. Plitt (Leipzig: Hirzel, 1868), 73).

${ }^{3}$ Form-Schrift, 41n, 43 [I, 92n, 94]. Translation modified.

${ }^{4}$ In the same year as the Form-Schrift, Schelling composed a study of the Timaeus.

${ }^{5}$ CPR, A313-318/B370-375.

${ }^{6}$ Letter to Hegel, 5 January 1795, Aus Schellings Leben, 73. Schelling's thinking here is closely intertwined with that of Hölderlin, who writes in a letter to Schiller, August 1797, that 'reason is the beginning of understanding' (Essays and Letters, trans. and ed. Jeremy Adler and Charlie Routh (Harmondsworth: Penguin, 2009), 92).
} 
considerations that move Schelling. Fichte aims to explain the concept not of philosophy but of the Wissenschaftslehre, and considers the bare notion of philosophy on which Schelling dwells, settled and unproblematic: the question which launches philosophical reflection is simply that of the possibility of ordinary first-order human knowledge of the basic empirical kind that also provides Kant's starting point. In Fichte's terms, the 'form of all philosophy' is simply whatever form renders natural consciousness self-transparent, and there is nothing at the level of total abstraction where Schelling wants to operate, that could provide a purchase for philosophical thought. The contrast sharpens when Schelling says that it cannot be assumed at the outset that philosophical knowledge is foundational for knowledge as such. ${ }^{7}$ The required argument is in fact extremely simple, and is completed in a couple of sentences, but the vital point is that, for Schelling, philosophical knowledge is strictly autonomous in relation to worldly cognition, not answerable to empirical consciousness. Each may therefore be said to take their initial stand in natural consciousness, but in different sectors thereof: Fichte starts with Kant's Erfahrung, empirical cognition, and Schelling with the natural metaphysical need of human reason, the part of ordinary thought that is already recognizably philosophical.

Further differences flow from this. For both, scepticism is of vital importance for philosophy in general, and the recent sceptical attacks on Kant's philosophy are highly instructive, but there is an appreciable difference in what each makes of the sceptical challenge. For Fichte, following the pattern of Descartes' First Meditation, scepticism constitutes simply a challenge to the certainty accompanying our ordinary claims to knowledge of an objective world. Its immediate import is not to engender first-order doubt - in Fichte's Kantian eyes, Descartes fails to make the vertical ascent of reflection which defines the transcendental turn - but to impress on us the need for a vindicatory explanation of the possibility of objective experience, our doxastic commitment to which does not need to be revoked in order for philosophy to begin, since it has become its explanandum. ${ }^{8}$

If on the other hand philosophy begins with an inalienable possession - self-cognition of its idea - then it also begins at a level above that at which the sceptic operates, neither needing the provocation of scepticism nor fearing anything from it, and as such is already in a position to make use of scepticism. Schelling's take on scepticism is consequently much closer to Spinoza's: in the instant that we absorb the full force of radical sceptical doubt, we also and thereby recognize the existence of a ground of knowledge - the indeterminately conceived non-objectual unconditioned, heterogeneous with all objects of knowledge and known in an utterly different way. In Spinoza's

\footnotetext{
${ }^{7}$ Form-Schrift, 41 [I, 91].

${ }^{8}$ The attitude to scepticism described here is held aside in The Vocation of Man, which (exceptionally) follows the design of the Meditations.
} 
image, the darkness that the sceptic seeks to cast over human knowledge merely reveals the light without which nothing could be put in the shadows. ${ }^{9}$

What allows Schelling to treat scepticism in this unconventionally platonistic fashion - to interpret it as directly revealing the non-emptiness of Kant's idea of the unconditioned, thus as giving more than it threatened to take away - he owes to Jacobi. ${ }^{10}$ The moral that Jacobi extracted from his consideration of Spinoza, developed in his David Hume on Faith, or Idealism and Realism (1787), is that philosophical reflection demands, but discovers that it cannot supply, knowledge of the unconditioned, its ideas of which are empty; and this confession of inadequacy forces it to relinquish its authority and cede to immediate feeling, Glaube, as the true condition for all knowledge. Schelling takes Jacobi's argument but subverts his anti-intellectualist conclusion: what the discovery of the unconditioned shows is not that philosophy must dissolve its systematic ambition but that its forms of reflection must be of an appropriately innovative, non-ordinary kind. Scepticism delivers this forward-looking result because it proves the insufficiency of chains of connection between conditioneds, i.e. causal and inferential relations, to sustain the realm which they collectively compose, and since this realm must subsist - every move we make in the web of the conditioned, including the sceptic's own inferences, shows it to do so - the unconditioned must have reality qua its ground. ${ }^{11}$

Second, in consequence of its platonic orientation, Schelling's project naturally attaches itself to an element in Kant's system that, though it can be accommodated in some form by the Wissenschaftslehre, has no urgent importance for Fichte: the so-called Transcendental Ideal, reason's idea of the sum-total of realities (Realitäten). ${ }^{12}$ This specific idea of the unconditioned, Kant argues, is formed when we reflect on the possibility of thought of determinate existents when we ask out of what metaphysical materials our thoughts of determinate objects are constructed - and theoretical reason fashions its idea of God around it. What allows it to be taken up immediately by Schelling are two points already made, which naturally conjoin: since philosophy by virtue of its very idea is committed to an Ur-Form of all forms, and scepticism has revealed, as antecendently given, the reality of the unconditioned, what we may legitimately suppose is that the form which gives reality to the idea of philosophy doubles as the real metaphysical ground of the objects of cognition. Hence Schelling's declaration, immediately after announcing the necessity of

\footnotetext{
${ }^{9}$ Spinoza, Ethics, IIp43s; Schelling, Ich-Schrift, in The Unconditional in Human Knowledge, 66 [I, 155$]$.

${ }^{10}$ See Ich-Schrift, 67 [I, 156].

${ }^{11}$ Fichte's own reception of Jacobi has a different character, and addresses a quite distinct aspect of Jacobi's critique of philosophy: he repeatedly returns to, seeking to rebut, Jacobi's claim that Wissenschaft entails alienation from Leben: see, e.g., Fichte's last letter to Jacobi, 3 May 1810 (GA III/6: 321-330).

${ }^{12}$ CPR, A571-577/B599-605.
} 
the unconditioned, that the 'form' which the Form-Schrift aims to lay bare will also be sufficient for all content - rendering it indistinguishable from Kant's Transcendental Ideal. This last claim is mirrored in Fichte, but again it is maintained for different reasons and in an importantly different sense: the sufficiency of the foundational principles of the Wissenschaftslehre for all content derives directly from consideration of what is necessary for cognition, i.e., for X qua object or content of cognition, a qualification not made by Schelling, for whom the (again platonistic) possibility is left open, even if not yet fully developed, that 'form' is directly productive, ontologically creative of content.

A contrast of epistemological strategies has emerged: Fichte's adheres to the binary subjectobject structure of cognition, while Schelling retains a third term, which underwrites ordinary cognition but is not exhausted by that role, hence not reducible to a 'transcendental condition'; Fichte holds to the unequivocally idealistic thesis of Kant's Fourth Paralogism - that all of the being with which (theoretical) philosophy is concerned must be treated exclusively in terms of its candidacy for being cognized - while residues of Leibniz are detectable in Schelling, who is drawn to the notion that structures within reality which obtain independently of our cognition provide its correct explanation. ${ }^{13}$ These differences become lost from sight, however, as soon as, in the next step of their common argument, the I enters the picture as fulfilling the conditions laid down.

Schelling's second 'Fichtean' text, Of the I as Principle of Philosophy, or On the Unconditional in Human Knowledge (Ich-Schrift), argues that properties of the I uncovered in Kant's account of transcendental apperception but not spelled out by Kant, equip it for the role of highest principle: unconditionability, pure unity, identity, reflexivity, self-realizability, equivalence of thought and being, and (most importantly) non-objectifiability. The line of thought is familiar from the Wissenschaftslehre, but there is a difference in the order of argumentation. As we have seen, Concerning the Concept extracts the unconditioned from the needs of cognition, whereas the Form-Schrift grants it a primordial independent existence. For Fichte, then, the necessity of the unconditioned designates a mere role which remains unoccupied until filled by the I, which is supplied (more clearly in the later Jena presentation than in the 1794-95 Wissenschaftslehre) by the intuited actuality of the philosopher's self-consciousness, wherewith ontological commitment begins. The Form-Schrift argues quite differently: Because the unconditioned is self-realizing, it must posit itself, and as self-positing, it must be 'I', absolute I. ${ }^{14}$

Schelling's argument raises a question, with repercussions which will emerge. It is not fully obvious that the self-positing unconditioned should be identified as an I, however much it fits the

\footnotetext{
${ }^{13}$ Schelling thinks that something must be salvaged from the 'middle way' of the 'preformation system' described (and rejected) in the Critique of Pure Reason (B167).

${ }^{14}$ Form-Schrift, 45 [I, 96-97].
} 
bill. Could there not be another, perhaps higher, fundamental kind of unconditioned reflexive entity than the I? Indeed, the identification is open to an objection: If we arrive at our understanding of the I via self-consciousness, and if self-consciousness is a one-in-many, how can 'I' justifiably be transferred to what is merely one logical moment of the complex configuration which composes Ihood? Considered as absolute, 'I' is a part, and it may be asked what entitles it to bear the title of the whole. Now this issue does not arise, or at least it does not do so in the same way, for Fichte, since he begins with the self-consciousness that is given to us, and if pressed to justify his identification of the absolute I as an I, Fichte has an argument: The designation is justified in view of the fact that it is only qua and by way of its role within self-consciousness, that we have any concept of it at all; we are concerned with the absolute I only so far as it provides the moment of identity in selfconsciousness, and whatever it might be apart from that (if indeed that supposition has meaning) is irrelevant. ${ }^{15}$ This answer is effective so long as no competing designation - no other angle, independent from the I, from which the absolute ground of its self-identity might be conceived - is in the offing, and in the Form-Schrift and Ich-Schrift, where no wedge is driven between I-hood and the reflexivity of the absolute, it is endorsed implicitly by Schelling.

\section{Gradual divergence and eventual opposition, 1795-1802}

But it is retracted as soon as Schelling comes to think that there is indeed an alternative. This realization is expressed in Schelling's formulation of the possibility of a new kind of philosophy of nature, Naturphilosophie. But first to be considered is the new position articulated in the third of his early texts, Philosophical Letters on Dogmatism and Criticism (1795). ${ }^{16}$

The Philosophical Letters, though composed only shortly after the Ich-Schrift, picture the philosophical options quite differently. Schelling begins with the claim that the prized Kantian distinction between dogmatism and criticism has been badly drawn. His intention, however, is not to reestablish Kant's understanding of the distinction but to contest it, by showing that it fails to mark off legitimate from illegitimate philosophical enquiry. Two strong claims are made. First, that contemporary Kantianism has been misappropriated to retrograde ends and infected by dogmatic elements that have no place in a system of freedom. ${ }^{17}$ This is of course Fichte's view too. The

\footnotetext{
15 The German Romantic alternative, dissatisfied with Fichte's answer, branches off at exactly this point. That the ground of the self's unity cannot be designated I, for the sorts of reasons indicated, is the argument of Hölderlin's fragment on judgement and being (1795) (Essays and Letters, 231-232), and of Novalis' Fichte Studies (1795-96), trans. and ed. Jane Kneller (Cambridge: Cambridge University Press, 2003).

${ }^{16}$ Which Schelling refers back to, in his late correspondence with Fichte, as evidence of the $a b$ initio independence of his standpoint from Fichte's (3 October 1801, Rupture, 61). The claim is repeated in Grounding of Positive Philosophy (1842-43), trans. and ed. Bruce Matthews (Albany, NY: SUNY Press, 2007), 146 [XIII, 82].

${ }^{17}$ See again Schelling's 5 January 1795 letter to Hegel, Aus Schellings Leben, 71-72.
} 
second is that what Kantians call dogmatism, and set in opposition to criticism, in fact contains elements that it either shares with Kantianism, or that Kantianism needs in order to achieve the adequacy it presently lacks (as will become clearer, Schelling tells his readers, when the 'new dogmatic system' presently under construction is made public ${ }^{18}$ ). This second claim is of course not Fichte's: though he agrees that Kant's philosophy is incomplete, Fichte does not consider that early modern rationalism contains what is needed in order to make it complete, on the contrary, this is to be achieved by accentuating its distinctively Kantian, anti-dogmatic characteristics.

In relation to Fichte, the burning question raised by the Philosophical Letters is whether the main argument that Schelling gives in support of his central contentions disagrees with the Wissenschaftslehre, even if nothing of the sort is intimated in the text. The mark of 'dogmatic' Kantianism, according to Schelling, is its endorsement of the two-part strategy exemplified in Kant's moral theology, what Kant calls his 'practico-dogmatic metaphysics': first the competence of theoretical reason is weakened (Kant's Transcendental Dialectic), then the items identified as exceeding its grasp are restored to reason in the form of 'practical cognitions' (Kant's postulates of pure practical reason). The strategy, Schelling insists, in agreement with Jacobi and many other contemporary critics, is on Kant's own terms incoherent: since Kant's postulates of God and immortality, though supposedly only fit topics of 'practical faith', are theoretical in form, they must be accepted as true; but if practical reason can cognize noumenal objects, either it at that point itself becomes theoretical, or it must hand over its discovery to theoretical reason, and if this is not possible, then no genuine cognition can have taken place. The basis for Schelling's second claim is now clear: if non-empirical cognition is not to be sacrificed, then theoretical reason must be restrengthened, which will involve retrieving for it at least some of the cognitive power affirmed by the ('dogmatic') early modern rationalists - and this is entirely possible, Schelling argues, because the Critique of Pure Reason did not in fact refute dogmatism. The implication is that appeal to practical reason is either ill-conceived or redundant, and this is where the potential rub with Fichte lies.

There are, it is true, grounds for denying that Schelling's attack on practico-dogmatic Kantianism has application to Fichte, who does not assert the weakness as such of theoretical reason, and whose thesis of the primacy of the practical, as articulated in Part Three of the 1794-95 Wissenschaftslehre, is quite different from Kant's principle bearing that name. However, it is also true (first) that Fichte motivates his practicalism by affirming, not merely a limitation on the objectgrasping scope of theoretical reason, but an actual contradiction within it, and (second) that he identifies the supremacy of practical reason with the categoricality of moral demands - an

\footnotetext{
${ }^{18}$ Philosophical Letters, in The Unconditional in Human Knowledge, 156 [I, 283].
} 
alignment which in Schelling's eyes disqualifies it, by subordinating the unconditioned to the inherent conditionedness of morality. ${ }^{19}$ Again we see Fichte and Schelling silently diverging: Schelling endorses the primacy of the practical only in the sense of the primacy of freedom, by which he understands the metaphysical priority of the unconditioned and its expression in finite consciousness (the act with which philosophy begins); Fichte's intricate argument for subordinating our conception of what is the case, to that of what ought to be the case, is not even addressed in the Philosophical Letters, because Schelling sees no need for it. The importance of this will emerge later.

The Philosophical Letters conclude with a hint in the direction of the Naturphilosophie that Schelling began to develop in $1797,{ }^{20}$ but the foundations of this large-scale project - which defined an entire research programme for the Goethezeit, and earned for Schelling a renown among his contemporaries never enjoyed by Fichte - lie in a nexus of assumptions alien to the Wissenschaftslehre. At one level, Schelling is merely re-posing Kant's question of the metaphysical foundations of natural science, and offering different solutions, allegedly superior to Kant's, to the problems of physics, chemistry and the life sciences. This establishes a limited contrast with Fichte, who of course accepts that this enquiry is legitimate, but whose discussions of natural science are relatively schematic and stick close to Kant. ${ }^{21}$ Schelling's new agenda is in fact, however, profoundly radical, for his central claim is that the results of natural scientific enquiry - when liberated from empiricism - show Nature to be infinite productive activity. The activity is Nature's own - it constitutes natura naturans - not the I's act of positing. In ascribing to natural science a metaphysical significance independent of transcendental sources, Schelling grants the a posteriori privileges which Kant and Fichte reserve for the a priori: his claim is that natural science and speculative metaphysics can be joined in a spekulative Physik yielding cognitions of Nature which do not derive from Kantian principles of experience or Fichtean self-consciousness but which nonetheless share the necessity of the a priori. And since the ground of these cognitions is not subjective, they afford knowledge of Nature as something which is, like Kant's thing in itself, 'actual for itself'. ${ }^{22}$

\footnotetext{
${ }^{19}$ Ich-Schrift, 98 [I, 199]. The moral law concerns not the I as such but as subject, 'conditioned by mutability and multiplicity'.

20 The way is now open for 'exploration of nature' (Philosophical Letters, 195 [I, 341]). The concept of Naturphilosophie is introduced in Ideas for a Philosophy of Nature (1797, 2nd and revised edn 1803), trans. Errol E. Harris and Peter Heath (Cambridge: Cambridge University Press, 1988).

${ }^{21}$ See, as indicative, the brief discussion of organisms in Foundations of Natural Right, (GA I/3: 378-379; FNR, 72-74), which follows the pattern of Kant's moral teleology of nature in the Third Critique.
}

${ }^{22} \mathrm{CPR}, \mathrm{Bxx}$. 
How exactly Schelling's project of Naturphilosophie might relate to the Wissenschaftslehre is an issue pending, but clearly it contradicts Fichte's claim for its philosophical exhaustiveness. At one point in their late correspondence, noteworthy for what seems Schelling's abrupt appeal to ordinary understanding, Schelling pinpoints what seems to him absurd in Fichte's exclusively transcendental approach to Nature:

It is sufficiently known to me in what small region of consciousness nature might fall according to your idea of it. It has for you absolutely no speculative significance, only a teleological one. But ought you really to be of the opinion, e.g., that there is light only so that rational beings when they talk to one another can also see each other, and there is air solely so that when they hear each other they can also speak to one another? ${ }^{23}$

Schelling may be interpreted as countering Fichte's strategy in his First Introduction to the Wissenschaftslehre (1797) for concluding in favour of idealism and against dogmatism - his claim being that Nature possesses the same kind of absolutely primitive authority for philosophical reflection as Fichte claims for self-consciousness. If Nature in all of its immeasurable might and infinite richness gives itself to us as existing in its own right and thus beyond mere transcendental warrant, ${ }^{24}$ then the asymmetry Fichte asserts is unjustified: pace Fichte, the not-I must be regarded as existing for itself, ${ }^{25}$ and the foundation of dogmatism validates itself in the same way as that of idealism; if an idealistically overhauled Spinozism installs reflexive activity at the very basis of Nature, then Fichte's assertion that dogmatism is necessarily blind to the reality of I-hood is rebutted. Though one and the same structure is exhibited by Naturphilosophie and the Wissenschaftslehre, and the arguments on each side run in a curious parallel, the disagreement of Fichte and Schelling concerning the reality of Nature involves no misunderstanding, and when Fichte asserts that Nature exists only in order to be subjugated and made transparent, and that moral meaning is the only kind it can have,${ }^{26}$ no reconciliation is possible.

\footnotetext{
${ }^{23}$ Letter of 3 October 1801, Rupture, 64 (translation modified). Schelling of course also views light 'teleologically', but Schelling's telos is not fulfilment of our rational need. Schelling is referring to claims of Fichte's in Foundations of Natural Right (GA I/3: 371, 376-377; FNR, 65, 71). The fourth and fifth theorems (§§5-6) of this work comprise a deduction of the human body under the rubric 'applicability of the concept of right'.

${ }^{24}$ For Schelling, sharing Goethe's scientific sensibility and influenced by Hölderlin, this notion approaches selfevidence. It stands in close connection with the ethico-aesthetic vision described in the Philosophical Letters as a corrective to the Kantian ethic of autonomy (159-160, 183-184, 187-188 [I, 288-289, 322-323, 328-329]).

${ }^{25}$ GA I/4: 196; IWL, 21.

${ }^{26}$ Vocation of Man (GA I/6: 266-269; VM $2,82-83$ ), and Darstellung der Wissenschaftslehre (1801-02) (GA II/6: 296297).
} 
Naturphilosophie opens up the possibility that the Wissenschaftslehre might be supplanted or superseded. All that is required, it would seem, is for some account to be given of the genesis of the individual finite I within Nature; a system of philosophy constructed around Naturphilosophie might then be held to answer the same questions, and to satisfy the same formal requirements, as the Wissenschaftslehre, while doing less violence to common-sense realism. Schelling is certainly tempted by this option, and goes so far as to assert the priority of Naturphilosophie over idealism, ${ }^{27}$ but decides against it. The final eclipsing of Fichtean idealism is the work of the Identity Philosophy that Schelling presents in 1801, and it is not a direct development of Naturphilosophie of the sort just described. To simply substitute Nature for the I would be to identify the absolute with a single conceptual form, and hence to reproduce, by a simple reversal, the structure of Fichte's system, thereby failing to grasp what Schelling now understands, more clearly than before, as the essentially indifferent character of the absolute, its transcendence of both subjectivity and objectivity. If to fix the absolute is to make it determinate and thus to destroy it, the problem is now to find some way of articulating it in a system. Schelling's initial solution, in the System of Transcendental Idealism (1800), was to develop the dual standpoint structure sketched in the Philosophical Letters, by allowing transcendentalism and Naturphilosophie to parallel one another. ${ }^{28}$ That Schelling became rapidly dissatisfied with this bipartite arrangement, or at any rate came to think that it could be overtaken, is clear from the opening axioms of his 1801 Presentation of My System of Philosophy. ${ }^{29}$ Reason, now identified with the 'total indifference of the subjective and objective' outside which there is nothing, is declared absolute, and since the standpoint of philosophy is that of reason, it follows that there 'is no philosophy except from the standpoint of the absolute'. ${ }^{30}$ This disposes of Kant and Fichte's perspectivism: if philosophical reason can grasp Reason immediately, by abstracting from the subjective element in intellectual intuition, ${ }^{31}$ then it can access directly, independently of the self-reflection of finite self-consciousness, the structures that compose reality and ground cognition. To the extent that residues of transcendentalism remain,

\footnotetext{
27 'Allgemeine Deduktion des dynamischen Prozesses oder der Kategorien der Physik' (1800), §63 [IV, 75-78], and 'Über den wahren Begriff der Naturphilosophie' (1801) [IV, 298-303]. Such a system would in fact have borne a high degree of similarity, as regards its basic structure, to Herder's Spinozism.

${ }^{28}$ Schelling's Treatises Explicatory of the Idealism of the Wissenschaftslehre (1797-98), in Idealism and the Endgame of Theory: Three Essays, trans. Thomas Pfau (Albany, NY: State University of New York Press, 1994), re-exposit (and defend against criticism) Fichtean transcendental philosophy in a way that anticipates the System.

${ }^{29}$ Though not asserted as such in the Preface, where Schelling may be thought to pull his punches: Presentation of My System of Philosophy (1801), trans. Michael Vater, in Rupture, 141-145 [IV, 107-114].

${ }^{30}$ Presentation, §§1-2, 145-146 [IV, 114-116].

${ }^{31}$ Presentation, in Rupture, 146 [IV, 114]: 'to come to the standpoint I require, one must abstract from what does the thinking'.
} 
they consist in the ascription of a certain relative spontaneity to our cognition (transcendental explanation), without any implication of a corresponding dependence of objects on our finite subjectivity (transcendental idealism). The Identity Philosophy represents the belated consummation of the programme laid out in the Form-Schrift, and it inaugurates absolute idealism.

The conception of philosophy with which Schelling began was richer than Fichte's in the sense of containing more elements, or at least of being answerable to stronger demands, and at the same time much less definite: in the Form-Schrift and Ich-Schrift, programmatic insights into the requirements of a complete system of philosophy exceed Schelling's suggestions of ways to satisfy them. This indefiniteness allowed Schelling to co-opt the Wissenschaftslehre at the outset, in so far as he found Fichte to have already worked out thoroughly one of the major lines of thought that he wanted to accommodate, concerning the unconditioned character of subjectivity. In those first two works, Fichtean idealism occupies almost all of the space available; subsequently, as Schelling found ways to develop the elements in his conception that exceeded the Wissenschaftslehre and that for him had greater importance, its portion shrank continuously, to the point of its eventual vanishing.

That Fichte's philosophy was indispensable for Schelling to reach this point - even if the ladder was discarded at the summit - is clear. If we ask whether, reciprocally, Schelling contributed in any way to Fichte's thought, what we find is extremely limited. Schelling's sustained reference to intellectual intuition in his Ich-Schrift may have alerted Fichte to its full potential, but Fichte had already drawn the connection, ${ }^{32}$ and its prominence in the later Jena Wissenschaftslehre is entirely explicable as due to his change of method from the 1794-95 Wissenschaftslehre. There are places where Fichte may seem momentarily to find a role for Naturphilosophie, ${ }^{33}$ but a succinct statement in a short unpublished piece from 1799-1800 confirms his determination to keep Nature within essentially Kantian bounds. ${ }^{34}$

Nor did Schelling succeed in leading Fichte to revise his original interpretation in the 179495 Wissenschaftslehre of Spinoza as sensitive to the same monistic considerations that motivate the Wissenschaftslehre, but miscarrying due to his failure to grasp the philosophical significance of the I. ${ }^{35}$ If Fichte ever agreed to relax the all-encompassing hold of the $\mathrm{I}$, it is in the versions of the

\footnotetext{
${ }^{32}$ Though not mentioned in the 1794-95 Wissenschaftslehre, it is affirmed in the earlier 'Review of Aenesidemus' (1794) (GA I/2: 48-57; EPW, 65, 70).

${ }^{33}$ E.g. GA I/4: 95-97; FNR, 264-266.

34 'Concerning the Nature of Animals' (1799-1800) (GA II/5: 421-430), in Fichte, The Science of Right, trans. A. E. Kroeger (Philadelphia: Lippincott, 1869), 495-505. Here Fichte argues that even organic nature can be grasped in terms of types of motion, as if adding a further chapter to Kant's Metaphysical Foundations of Natural Science.
}

${ }^{35}$ GA I/2: 262-264, 279-282; SK, 101-102, 117-119. 
Wissenschaftslehre from 1804 onwards that he does so. Here Fichte seems to want to demonstrate that, with suitable elaboration, but consistently with its founding principles, the Wissenschaftslehre can be shown to equal absolute idealism in philosophical import. It has been said that Fichte in the late Wissenschaftslehre betrays his earliest and best insights, misguidedly seeking to meet Schelling on his own terms. The question of the extent to which the late Wissenschaftslehre narrows Fichte's distance from Schelling cannot be pursued here, but one major consideration counts against the estimate of it as capitulating to absolute idealism: in all of its many versions in the late Wissenschaftslehre texts, the crux of the argument given for the postulation of the absolute consists in reflective attention to our very act of thinking of the absolute and thence to the reflectiontranscending preconditions of that act. These preconditions are now held to include an element that, contra the Jena Wissenschaftslehre, does not itself reside within intuition, but no abstraction from the very act of thinking, of the sort demanded by Schelling, is involved. The absolute that emerges from the late Wissenschaftslehre is anterior to self-consciousness, and qualifies as no less genuinely speculative and Verstand-transcendent than the Schellingian-Hegelian absolute, but it continues to be reached by Fichte's method of reflexive introversion; and because it remains fixed by the 'absolute knowing' of individual subjectivity, Fichte remains open to the charge of subjectivism that, we will shortly see, Schelling and Hegel level against him - Fichte's own position being, all the way to the end, that no other absoluteness is intelligible.

\section{Being and knowing, and Is and Ought}

Aside from its historical importance, the opposition of Fichte and Schelling holds major systematic interest: it tells us something about the deep structure of the Kantian idealist project, just as Locke and Berkeley reveal something fundamental about the nature of empiricism. And in so far as they present us with a kind of antinomy - that is, in so far as their rival forms of post-Kantianism seem equally warranted - some insight into their systematic opposition is needed. The issues here are of course highly intricate, and merit extended investigation; what follows picks out only one thread.

We may begin by asking to what extent Schelling can legitimately claim, in virtue of his development of an alternative form of post-Kantian idealism, to have exposed weaknesses in Fichte's position. If Schelling's criticisms of Fichte ${ }^{36}$ are compared with those of other

\footnotetext{
${ }^{36}$ In addition to the 1801-02 letters, important texts include 'On the Relationship of The Philosophy of Nature to Philosophy in General' (1802), Sect. 1, in George di Giovanni and H. S. Harris (eds), Between Kant and Hegel: Texts in the Development of Post-Kantian Idealism, revised edn (Indianapolis/Cambridge: Hackett, 2000), 368-373 [V, 108115]; Darlegung des wahren Verhältnisses der Naturphilosophie zur verbesserten Fichteschen Lehre (1806) [VII, 1181], esp. 21-39; On the History of Modern Philosophy (1833-34/1836-37[?]), trans. Andrew Bowie (Cambridge: Cambridge University Press, 1994), 106-113 [X, 90-98]; and Grounding of Positive Philosophy, 124-128 [XIII, 51-57].
} 
contemporaries - for example, Kant's associate Jakob Sigismund Beck, in an early and highly critical review of the 1794-95 Wissenschaftslehre ${ }^{37}$ - it is striking how they have nothing to do with allegations of emptiness and unintelligibility, or of arbitrary departure from Kantian orthodoxy, the usual complaints, nor does Schelling impugn the Wissenschaftslehre's derivation of objectivity from subjectivity. Schelling's misgivings concern the overarching design of Fichte's philosophy: the problem lies not within the derivation but in what Fichte claims on its behalf, that is, in his conception of what counts as fulfilling his stated aim of absolutizing Kant's philosophy. In making this criticism, and in all of his substantive divergences from Fichte, Schelling relies ultimately, as we have seen, on high-level assumptions - elements of platonism and rationalism, a Romantic conviction of the metaphysical significance of Nature - that Fichte does not share, and while Schelling may suppose that Fichte is bound to recognize the superiority of his own estimate of the philosophical possibilities available in the wake of Kant, whether this is so must remain moot. As such, Schelling's criticisms are neither straightforwardly internal nor external, and their effectiveness depends in good part on his success in developing an alternative to the Wissenschaftslehre.

Several themes occupy Fichte and Schelling in their 1800-02 correspondence, but the most important - the one that appears potentially decisive - is also, as might be expected, the most abstract: the relation of being and cognition. ${ }^{38}$ According to Schelling, Fichte's prioritization of cognition over being is fatal:

I might say that, in order to maintain your system, one must first decide to start from seeing [Sehen] and end with the absolute ... The necessity to proceed from seeing confines you and your philosophy in a thoroughly conditioned series in which no trace of the absolute can be encountered. ${ }^{39}$

\footnotetext{
${ }^{37}$ Annalen der Philosophie und des philosophischen Geist, Bd. I, St. 16 (6 February 1795), 121-124, and St. 17 (9 February 1795), 129-144. Other landmark criticisms of the Wissenschaftslehre - additional to those (already mentioned) of the German Romantics, which remained unpublished, and Hegel's early texts (cited below) - include Jacobi's open letter to Fichte in 1799 (The Main Philosophical Writings and the Novel Allwill, ed. and trans. George di Giovanni (Montreal: McGill-Queen's University Press, 1994), 497-536), Kant's open letter of the same year (which contains no real criticism but simply repudiates Fichte's project), and the novelist Jean Paul's Jacobi-aligned polemic, Clavis Fichtiana seu Leibgeberiana (1800).

${ }^{38}$ Fichte defines his difference from Schelling in just these terms in his notes on Schelling's System - 'I say all being is only in relation to knowing. He replies to me: no, all knowing is only a kind of being' - and interprets Schelling's prioritization of being as an illusion generated by second-order reflection (GA II/5: 414; Rupture, 120).

${ }^{39}$ Letter of 3 October 1801, Rupture, 61 .
} 
You are consequently compelled, Schelling tells Fichte, to 'transfer the speculative domain into the sphere of faith [in The Vocation of Man], since you simply cannot find it in your knowing'. ${ }^{40}$ The inferior knowing of Fichte's merely 'reflective' philosophy reduces being - which in truth 'has no opposite' - to reality in the sense of mere actuality, Wirklichkeit. ${ }^{41}$

This contrast goes right back to the beginning. One pervasive theme in all three of the early 'Fichtean' texts discussed above, we saw, is Schelling's explicit ontological commitment: at every relevant point, Schelling emphasizes that the unconditioned, though we talk of it as 'posited', 'postulated' and so forth, as if its reality were still undecided, must be not merely thought as having being, but must have being; indeed Schelling adopts the key Spinozistic locution, saying that the unconditioned must be thinkable through its being. ${ }^{42}$ Of particular interest to Schelling in those essays is the traditional ontological argument, which he rejects as an argument purporting to move from a concept to an object by way of pure inference, and interprets as groping towards the important truth that the unconditioned is realized through itself (it misrepresents this truth in the form of, so to speak, an 'argument' composing God's own cogito). ${ }^{43}$ Fichte's Jena texts, on the whole, downplay ontological idioms, and in places Fichte entertains the notion that the Wissenschaftslehre might be some sort of fiction or mere 'model' of mental acts, validated by its results - its derivation and validation of the facts of experience as we know them - and not in need of truth in any more realistic, correspondence-style sense. There are in addition striking passages where Fichte draws a sharp distinction between 'activity', which defines thought and intuition, and 'being', which defines its objects. ${ }^{44}$

Schelling's ontological emphasis is sometimes glossed as a preference for Kant's 'constitutive' as against Fichte's attachment to the 'regulative', but this by itself explains little, nor is much gained by describing Fichte as assuming the priority, which Schelling reverses, of epistemology over ontology. What is needed is some account of why Schelling elevates and Fichte subordinates ontological commitment. With this end in view, we may turn to a long-standing issue in the interpretation of the Wissenschaftslehre: Does the absolute I exist?

On the one hand it would seem that it must do so, because it corresponds to an essential component of the 'one-in-many' of self-consciousness: it is what supplies the pole of identity which unifies its 'many', the subject-I and object-I of the I as an Intelligenz, and since the reality of self-

\footnotetext{
${ }^{40}$ Ibid.

${ }^{41}$ Rupture, 60.

${ }^{42}$ See Ich-Schrift, 72, 89-92, 100 [I, 163, 186-192, 202]: the Urform of the I is 'that of the pure eternal being'; the connection with Jacobi is indicated at 67 [I, 156].

${ }^{43}$ Ich-Schrift, 76n [I, 168n].

${ }^{44}$ See the Second Introduction to the Wissenschaftslehre (GA I/4: 225; IWL, 56 and GA IV/2: 39; FTP, 131).
} 
consciousness is beyond question, so too must be that of the absolute I. The commitment to existence cannot be evaded, arguably, since the Wissenschaftslehre requires us to take as true the principles with which it begins, and even if (contra Fichte) ' $\mathrm{X}=\mathrm{X}^{\prime}$ and other truths of general as opposed to transcendental logic could do so, the truth of a proposition with content - here, the Icannot subsist without being made true by something that exists; what is taken as true in the first principle is, after all, not the necessity of our believing that the I posits itself absolutely, but simply the I's positing itself absolutely. ${ }^{45}$

Yet the opposite view also appears compelling. Though the Wissenschaftslehre begins with the I's self-positing, its Theoretical Part concludes with an aporia, consequent upon the realization that the contradiction formed by its first and second principles, and reproduced within the second principle, cannot be dissolved in thought, whereupon the task of practical reason is defined, and the priority of practical over theoretical reason is disclosed. Hence the absolute I is only what merely ought to exist: if it had actual existence, then it could not function as the idea that constitutes and determines practical reason, for it could not exert the pressure - the necessity of giving being to what does not yet have being - that makes the I a striving. To accord real existence to the I, it may be added, would be to assimilate the Wissenschaftslehre to a pre-Critical metaphysics and thereby miss what is most revolutionary in it, Fichte's application of a practical turn to Kant's Copernican revolution in theoretical philosophy.

Suggestions have been made for how to finesse this seeming contradiction, but whatever solution might be available is not gleaned easily from Fichte's texts, and the fact that a charge of unresolved confusion concerning the absolute I stands at the centre of Hegel's extended critique of Fichte (and correlative defence of Schelling) in his early Kritisches Journal writings, testifies to the difficulty. ${ }^{46}$ And once it has been identified, it is not hard to see how it can be developed into a more fundamental critique of the Wissenschaftslehre, in the following way.

A contrast may be drawn between Fichte and Schelling's respective appropriations of Kant, which may seem strongly favourable to Schelling. If Fichte's philosophy can be glossed as the subsumption of Kant's First Critique under his Second, Schelling's can be regarded as born from the Third. This is true in the obvious sense that issues concerning art and the aesthetic, and natural teleology, are to the fore in Schelling but of limited significance for Fichte. However, it is not these themes in the Critique of the Power of Judgement, enormously important as they are for Schelling,

\footnotetext{
45 '[W] hat does not exist, cannot posit' (GA I/2: 389; SK, 222).

${ }^{46}$ Hegel, The Difference between Fichte's and Schelling's System of Philosophy (1801), trans. H. S. Harris and Walter Cerf (Albany, NY: SUNY Press, 1977), 129-135, 155-161, and Faith and Knowledge (1802), trans. H. S. Harris and Walter Cerf (Albany, NY: SUNY Press, 1977), Part C. See Wayne Martin, 'In Defense of Bad Infinity: A Fichtean Response to Hegel's Differenzschrift', Bulletin of the Hegel Society of Great Britain, 55/56 (2007): 168-187.
} 
but rather its famous sections $\$ \S 76-77$, in which Kant presents his theory of the intuitive intellect, that represent for him pure gold. ${ }^{47}$ Here Kant argues that the distinctions of the actual from the merely possible, and of what is the case from what ought to be the case, have no application to reality as given to an intuitive intellect. And because Kant not only identifies the features which differentiate our cognition from God's, but also explains the systematic interrelation of the two modes of cognition, he at the same time instructs us as to how we might extrapolate from our own finite cognition to divine cognition, meaning that our cognition can, in a certain sense, become infinite: by cognizing itself in the terms made available in $\$ \S 76-77$, it inverts its own finitude. Following this construal of Kant's true (but arrested) trajectory in the Third Critique, Schelling undertakes to unify Freedom and Nature by means of a speculative theory of their common subjecttranscendent supersensible ground, in contrast with Fichte's more faithfully Kantian construal of the task as directed towards the intra-subjective unification of our ways of thinking about Freedom and about Nature: Fichte's position is that Freedom and Nature are unified, so long as we can grasp the original point of differentiation of our reason into its theoretical and practical forms; Schelling's is that it requires the postulation of a point which is in itself, in abstraction from our reason, equidistant - 'indifferent' - between, and yet that also grounds, Freedom and Nature.

With all this in place, it is easy to understand Schelling's conviction, co-formed with Hegel in their years of cooperation at Jena, that Fichte's philosophy is 'one-sidedly subjective', hence incapable of grasping the absolute, or true being: Fichte may be charged with failing to grasp the significance of Kant's demonstration in $§ \S 76-77$, as Schelling and Hegel understand it, that in order to get beyond a transcendental idealism of 'mere appearances' correlated with unknowable things in themselves, it is necessary to posit an absolute that fully transcends finite self-consciousness. ${ }^{48}$ Fichte's project thus appears a compromise, its confusions concentrated in a supposedly final 'absolute I', which incoherently superimposes differentiation, the structure and relationality of selfconsciousness, on an identity that, for the sake of its absoluteness, precludes such features. And because $\$ \S 76-77$ belong to the Kantian legacy, Schelling can claim that his criticism of the Wissenschaftslehre is genuinely internal.

Now that we have a clear idea of the charge facing Fichte, it is equally clear that much may be said in reply. In the first place, Fichte agrees that the validation of a philosophical system involves its agreement with the standpoint of divinity: God would recognize, Fichte claims, the

\footnotetext{
${ }^{47}$ The role of this concept in German Idealism receives its fullest treatment in Eckart Förster, The Twenty-Five Years of Philosophy: A Systematic Reconstruction, trans. Brady Bowman (Cambridge, MA: Harvard University Press, 2012).

${ }^{48}$ Schelling puts his criticism this way in his letter of 3 October 1801 (Rupture, 60); Schelling refers to '\$74, Remark', but must have $§ 76$ in mind.
} 
'formal correctness' of the Wissenschaftslehre, though not its content. ${ }^{49}$ This formal correctness consists in the parallelism of Is and Ought which provides its overarching structure: the absolute I that has being at one end is the absolute I that ought to have being at the other. Fichte has therefore incorporated, albeit in a different way from Schelling, the insight of $\S \S 76-77$ that, for an intuitive intellect, Is and Ought co-refer. It is this, furthermore, that dissolves the seeming contradiction in the Wissenschaftslehre concerning the existence of the absolute I, and demonstrates its coherence: the unconditioned ' $\mathrm{X}$ ' which is needed to render absolute Kant's philosophy absolute can be determined both as posited absolutely by theoretical reason and as an idea to be realized by practical reason, and as both 'absolute' and 'I', because $\S \S 76-77$ license us to overlay these distinct conceptions at the extreme limit of philosophical reflection, placing them at the beginning and the end-point of our Wissenschaft. To the extent that this structure invokes something akin to an indifference point, it is one validated by intuition. Fichte may accordingly claim to have shown that Freedom and Nature can be unified in an absolute without resort to aesthetics or teleology, by developing and fusing central doctrines of the First and Second Critiques. The charge of failing to take the lesson of the Third Critique then misses the mark.

What remains true is just that Fichte, though making appeal to intellectual intuition, does not incorporate the full theory of the intuitive intellect as Schelling understands it into his methodology, which remains Kantianly circumscribed by self-consciousness. But this too has a justification, which lies in (again faithfully Kantian) considerations concerning the necessary conditions of discursive meaningfulness - which, Fichte may point out, are no less prima facie implications of $\S \S 76-77$ than the positive doctrines that Schelling wants to extract from those sections. According to Fichte, the incomprehensible may figure in philosophical reflection in two different ways. Legitimate reference to what eludes comprehension occurs when on reaching the boundaries of thought we are redirected to the intuitional foundations of conceptualization - as when it is grasped that the I cannot be grasped by purely discursive means. Here intuition steps in to certify the reality of the incomprehensible and render intelligible its resistance to discursive articulation. Where intuition is unavailable, the incomprehensible reduces to sheer meaninglessness - as when the concept of the thing in itself is discarded as nonsensical. On Fichte's diagnosis, Schelling's position results from a failure to see that the resources of meaning available to a finite intellect are not infinite, leading him to misconceive boundaries as mere limitations of the understanding which the higher power of reason can overcome; whence his key moves of positing absolute indifference and of detaching intellectual intuition from I-hood, which in Fichte's eyes lapse into empty

\footnotetext{
${ }^{49}$ GA I/2: 390-391; SK, 224.
} 
incomprehensibility. ${ }^{50}$ On Fichte's account, then, what Schelling and Hegel allege to be limitations of the Wissenschaftslehre, to be overcome, are in fact boundaries, to be respected, and their complaint that Fichte fails to sublate the subject-object opposition, and that his choice of (idealist) subjectivity over ('dogmatic') objectivity remains ultimately arbitrary, results from their failure to recognize the way in which the Wissenschaftslehre subordinates the subject-object polarity to that of Is-Ought. In fact there is nothing more to the intuitive intellect than the arc of thought that spans the separation of Is and Ought and prescribes our movement from the former to the latter: Schelling's claim to occupy its standpoint rests on a misreading of $\S \S 76-77$, which expands the selfunderstanding of the finite intellect, but does not license its self-assimilation to an infinite intellect a move which, if it comes to appear necessary, does so only because practical reason has been denied its proper role. ${ }^{51} \mathrm{Such}$, in brief reconstruction, is Fichte's reply to Schelling. ${ }^{52}$

Finally we may return to the contrasting positions of Fichte and Schelling regarding ontological commitment. What allows Schelling to subsume all under the concept of being - and then to declare, following Spinoza, that all reason is essentially theoretical and that all ethics must emerge from ontology ${ }^{53}$ - is his concept of the indifference point, from which all possible distinctions derive and in which they vanish. The reason for Fichte's abstention from global ontological commitment lies in an earlier point, concerning the grounds for thinking that the absolute I must lack existence: Because philosophical reflection cannot transcend the opposition of Is and Ought, it cannot pretend to a perspective like Spinoza's from which all things are spread out in full and equal ontological positivity; consequently the I must be conceived as activity prior to being, and the Ought as an irreducible feature of reality posited outside being. ${ }^{54}$

There are elements in Schelling's later development that Fichte, had he lived longer, might well have taken as bearing out his negative assessment of the absolute idealist project. In his writings from 1809 to 1815 , the period of his Freiheitsschrift and Weltalter texts, Schelling appears

\footnotetext{
50 'Announcement' (1800[01]), in Rupture, 87-88 (GA I/7: 157-160), 'Preparatory Work Contra Schelling' (1801), in Rupture, 120-122 (GA II/5: 483-485), and Darstellung (1801-02) (GA II/6: 198-199).

51 This has, Fichte may propose, a definite locale in the Ich-Schrift (97-98 [I, 199]), where Schelling in effect reduces the Ought to a mere representation of the 'natural law for the nonfinite I'.

${ }^{52}$ Key texts for Fichte's critique of Schelling include also the second 1804 Wissenschaftslehre (The Science of Knowing: J. G. Fichte's 1804 Lectures on the Wissenschaftslehre, trans. and ed. Walter W. Wright (Albany, NY: State University of New York Press, 2005)), Lecture 14, and Bericht über den Begriff der Wissenschaftslehre und die bisherigen Schicksale derselben (1806) (trans. by A. E. Kroeger as 'Fichte's Criticism of Schelling', Journal of Speculative Philosophy 12, 1878, 160-170, and 13, 1879, 225-244), esp. Ch. 2, Pt. 2.

${ }^{53}$ E.g., Ich-Schrift, 67-68 [I, 157].

${ }^{54}$ In the 1804 Wissenschaftslehre, 148-149, Fichte identifies the Sollen as what distinguishes his system from all predecessors (GA II/8: 302-305).
} 
to lose confidence in, indeed to turn against, the assumption - vital for his critique of Fichte - that being, identity and ground are fundamentally transparent notions that can be employed to define a subjectivity-transcending standpoint. This does not of course lead Schelling to reopen the case against the Wissenschaftslehre, but Fichte would be right to ask why he does not - especially when it is noted how close to sheer paradox Schelling appears to come in his philosophical writings after 1815. In his very late Grounding of Positive Philosophy (1842-43), Schelling writes:

We can produce everything that occurs in our experience a priori in mere thought, but as such it exists, of course, only in thought. If we wanted to transform this into an objective proposition - say, that everything in itself likewise exists only in thought, then we would have to return to the standpoint of a Fichtean idealism. If we want anything that exists outside of thought, then we must proceed from a being that is absolutely independent of all thought, which precedes all thought. ${ }^{55}$

The retort available to Fichte is clear: If the only way to avoid Fichtean idealism is to 'proceed from' a being that is absolutely independent from and precedes all thought, then the Wissenschaftslehre has all the proof it could ever need, for we cannot take as our starting point a place that we cannot even conceive of occupying. ${ }^{56}$

\footnotetext{
${ }^{55}$ Grounding of Positive Philosophy, 204 [XIII, 164].

${ }^{56}$ For further discussion of the Fichte-Schelling relation, see Rolf-Peter Horstmann, 'The Early Philosophy of Fichte and Schelling', in Karl Ameriks (ed.), The Cambridge Companion to German Idealism (Cambridge: Cambridge University Press, 2000), Frederick Beiser, German Idealism: The Struggle Against Subjectivism, 1781-1801 (Cambridge, MA: Harvard University Press, 2002), Pt. IV, Chs. 1-3, and Jörg Jantzen, Thomas Kisser, and Hartmut Traub (eds.), Grundlegung und Kritik. Der Briefwechsel zwischen Schelling und Fichte 1794-1802 (Amsterdam: Rodolpi, 2005).
} 
